\title{
Silviculture of high-quality oaks: questions and future research needs
}

\author{
GT Weaver 1, H Spiecker 2 \\ ${ }^{1}$ Department of Forestry, Wildlife and Fisheries, The University of Tennessee, PO Box 1071, \\ Knoxville, TN 37901-1071 USA; \\ 2 Institut für Waldwachstum Bertoldstr 17, DW-7800 Freiburg, Germany
}

(Received 6 January 1993; accepted 2 June 1993)

Summary - Oak forests are economically and ecologically important in Central Europe and eastern United States of America. In the former oak forests are being returned by artificial regeneration to many sites where oaks had been replaced by other species. Artificial and natural regeneration methods are being sought. Coppice forests are being replaced by forests of seed origin on many sites throughout Central Europe. Methods using wider spacing and shorter rotations which produce highquality timber adapted to site quality are being considered. In the USA reliable regeneration remains a key silvicultural problem. Effective means of both artificial and natural regeneration are being sought. Oak forest are and will be managed for a broader range of objectives in Central Europe and the USA. Future research needs include ecophysiology, growth and development, regeneration, silvicultural systems and oak decline.

\section{Quercus spp / silviculture / ecology / coppice / high forest / Central Europe / USA}

Résumé - Sylviculture des chênes de haute qualité. Questions et besoins en recherches futures. Les forêts de chênes sont économiquement et écologiquement importantes en Europe et dans l'est des États-Unis d'Amérique. Dans le premier cas, les chênaies sont revenues grâce à la régénération artificielle sur de nombreux sites où elles avaient été remplacées par d'autres espèces. Des méthodes pour la régénération naturelle et artificielle sont recherchées. Les taillis sont remplacés par des futaies dans beaucoup d'endroits en Europe. Les méthodes utilisant de larges espacements et des rotations courtes qui produisent des bois de haute qualité adaptés aux stations sont maintenant prises en considération. Aux États-Unis, une régénération efficace reste une des clés de la sylviculture. Des moyens performants de mise en œuvre de la régénération artificielle et de la régénération naturelle sont recherchés. Les chênaies sont et seront aménagées pour un très large éventail d'objectifs en Europe et aux États-Unis. Les besoins futurs en recherche incluent l'écophysiologie, la croissance et le développement, la régénération, les traitements sylvicoles et le dépérissement du chêne. 


\section{INTRODUCTION}

The Technical Session of P1 06 "Improvement and Silviculture of Oaks", held during the IUFRO Centennial Meeting at Eberswalde/Berlin in 1992, has 2 principal goals: 1) to determine the status of oak silviculture in Central Europe and the United States; and 2) to identify research that supports future management of oaks and oak forests.

Conditions, problems and trends identified by authors for various countries and major research needs have been summarized in this paper. On behalf of the participants at the sessions and those who will benefit from the published papers, our gratitude and appreciation are expressed to the authors for sharing their expertise and insights with us.

\section{PAST AND PRESENT}

The papers in this series stress the economic and ecological importance of oaks in the past and present in Central Europe and the United States. Their present economic importance is closely related to the percentage of valued wood produced. Ecological importance is due to the wide range of climatic provinces and sites presently or formerly occupied by oaks, and their importance as components of the wildlife habitat, and in the protection of soil and water resources. However, many present oak forests are not naturally established and do not occupy the full range of sites to which they are adapted. Conversely, many stands have been established and treated by silvicultural prescriptions with little consideration for suitability taking into consideration differences in site quality. The historical origins and past treatment of these stands are often uncertain and increase the uncertainty of preparing appropriate and effective prescriptions.

The history of present stands affects their current status, responses to treatment and potential for producing goods and services. These factors have to be considered when preparing silvicultural prescriptions. Coppice forests continue to predominate in many regions. These forests often produce stems of inferior quality and are generally regarded as less desirable than those from seeds or planted seedlings. A problem for silviculturalists is to determine how best to convert these stands to high forests (those originating from seed). Often, several age classes are unevenly distributed within management units, which complicates regeneration and management for sustained yield.

Artificial regeneration by planting and direct seeding with a tendency towards wider spacing prevails in Central Europe. Natural regeneration with various levels of weeding and tending have been successful in some regions. In the uplands of the United States, natural regeneration of oak forests is much more common but is incompletely understood and is unreliable under many conditions. Regeneration of oaks on high-quality sites is especially difficult and is a primary constraint to intensive oak silviculture. Techniques for overcoming this problem are being studied in several countries.

Ecophysiological factors, including drought resistance, light requirement and other environmental parameters have been studied for some important species. Individual tree parameters (crown dimension, stem diameter) and stand structure (density, age and species composition) have been studied for several European species. The relationship between growth and these parameters are known for some species, but effective practices for establishment, tending and thinning stands are inadequately known for most species. 
Tending and thinning of stands in Central Europe have traditionally maintained dense stands to produce wood with relatively narrow growth rings. Slower growth was believed to be necessary for the desired wood quality. Oak decline is of major concern both in Central Europe and eastern United States. Although specific causes have not been identified, research indicates physiological stress due to interacting factors (site conditions, drought, insects, diseases, tree age, genetics).

\section{FUTURE TRENDS}

Interest in both the economic and the ecological value of oaks will continue and probably increase in the future in Central Europe and the United States. When economic return is the goal, emphasis will be on high forests managed for maximum productivity - either through short rotation crops or on longer rotations for high valued timber. Past criteria for evaluating wood quality, especially the narrow width of growth rings, are being reevaluated. Trees with larger diameters, clear boles and wider growth rings will be sought. In forests managed for high-quality wood products, either natural regeneration or seeding or planting at wider spacing will be used to lower costs. Efficient management will be accomplished by several means, including selection of a relatively small number of crop trees and regulation of early stand development to concentrate site potential on these trees to produce large stems and desirable form. Also thinning and greater mixture of species in stands may become more important, as will site-related management decisions.

The trend is toward development of more efficient methods for natural and artificial regeneration in Central Europe and the United States. There is evidence that regeneration of some oak species by plant-ing may be successful using various shelterwood techniques in place of the more traditionally used clearcutting method. Additional information on the ecophysiological responses of many species to light levels, soil conditions and on growth relations of competing species will be needed to generalize prescriptions to other species and regions. The genetic diversity of many oak forests is unknown due to the uncertain origins of stands, seed sources and, in the United States, to repeated high-grading of stands. Assessment of genetic status of stands and techniques for genetic improvement of stands being regenerated are needed.

Restoration of natural oak woodland communities in Central Europe is of increasing interest. Species selection and silvicultural treatments should be adapted to sites and include mixtures of non-oak species. These forests will be managed increasingly as sustainable ecosystems for a wider range of products and services than at the present. Where economic return is important, systems to produce valuable crop trees will be needed. Integration of management for multiple outputs will be more important. Simultaneous consideration of economic aims, benefits to wildlife, aesthetics, recreation and soil and water protection will increase. New silvicultural systems will be required as the uses of oak forests diversify. However, oak silviculture remains very intensive and often expensive.

\section{FUTURE RESEARCH ACTIVITIES}

The status of oak forests and trends in their management in Central Europe and the United States as described in this series of papers suggest 5 broad areas for additional research. These areas, with spe- 
cific recommendations, follow. 1) Ecophysiology: determine the responses of several important species to varying site and environmental conditions, including anthropogenic environmental changes and to treatments for establishing, tending and thinning. 2) Growth and development: determine the relationship between growth of trees of several species and crown structure, stand structure (stocking and species composition) and site quality. 3) Regeneration: develop reliable natural regeneration methods for stands of mixed composition for a range of sites and environmental conditions. 4) Silvicultural systems: develop low-cost systems for managing natural oak woodland communities for a variety of goods and services. This includes: i) systems for a greater proportion of highvalued wood on shorter rotations $<100$ $\mathrm{yr}$ ); ii) systems for natural stands of more diverse species compositions for a greater combination of goods and services; iii) systems for integrated management where multiple output is desired. 5) Oak decline: determine the relation between oak decline and stand age and structure, species-site interactions, and pollutants, insects and pathogens and their regulation by silvicultural treatment. 